\title{
Difusi Produk Bioteknologi "Probiotik" Untuk Meningkatkan Produksi Ternak Ruminansia di Desa Lelede Kecamatan Kediri, Lombok Barat
}

\author{
Arafatul Ulfa', Mahfud Akbar' ${ }^{2}$, Jihad Akbar ${ }^{3}$, Muhamad Ali*3 \\ ${ }^{1}$ Pendidikan Bahasa Inggris, Fakultas Keguruan dan Ilmu Pendidikan, \\ ${ }^{2}$ Budidaya Perairan Fakultas Pertanian, \\ ${ }^{3}$ Fakultas Peternakan, Universitas Mataram, INDONESIA;
}

\author{
Article history \\ Received: 03 Juni 2019 \\ Revised: 14 Juni 2019 \\ Accepted: 14 Juni 2019 \\ *Corresponding Author: \\ Muhamad Ali \\ Fakultas Peternakan \\ Universitas Mataram, \\ Indonesia \\ Email*: m_ali@unram.ac.id
}

\begin{abstract}
The community of Lelede Village, Kediri District, West Lombok Regency, mostly cultivate goats and cattle. However, the cultivation of both types of livestock is still done traditionally using grass and agricultural waste as feed. From that case, the addition of microorganisms which has the ability to digest fiber is very important in order to optimize the digestion process of the feed. Probiotics are certain microorganisms that can help digestion and can minimize the presence of disease. In this activity the production and the use of probiotics has been diffused to improve the livestock production performance in Lelede Village, Kediri District, West Lombok Regency. The activity began with socialization of probiotics, training of probiotics production, and its used for ruminants. The training material consisted of the process of making probiotics started from measuring the dosage of ingredients, making inoculum, until the production of probiotics in fermentors. For the training, 35 farmers have been involved. The probiotics produced are then distributed to farmers for later given to livestock either through feed or drink water.
\end{abstract}

Keywords: feed; goat; cattle; fermentor; inokulum

Abtrak: Masyarakat Desa Lelede Kecamatan Kediri Kabupaten Lombok Barat sebagian besar melakukan budidaya ternak kambing dan sapi. Namun, budidaya kedua jenis ternak tersebut masih dilakukan secara tradisional hanya dengan menggunakan rumput dan limbah pertanian sebagai pakan. Untuk mengoptimalkan proses pencernaan pakan tersebut, adanya tambahan mikroorganisme yang memiliki kemampuan mencerna serat sangat penting. Probiotik merupakan mikroorganisme tertentu yang mampumembantu pencernaan dan dapat meminimalisir adanya penyakit. Pada kegiatan ini telah dilakukan difusi teknologi pembuatan dan penggunaan probiotik untuk meningkatkan kinerja produksi ternak di Desa Lelede Kecamatan Kediri Kabupaten Lombok Barat. Kegiatan dimulai dengan sosialisasi tentang probiotik, pelatihan pembuatan probiotik, serta penggunaannya untuk ternak ruminansia. Materi pelatihan terdiri dari proses pembuatan probiotik mulai dari mengukur takaran bahan, pembuatan inolukulum, hingga produksi probiotik dalam fermentor.Untuk pelatihan tersebut, telah dilibatkan 35 orang peternak. Probiotik yang dihasilkan kemudian dibagikan kepada peternak untuk selanjutnya diberikan kepada ternak baik melalui pakan maupun air minum.

Kata Kunci: pakan; kambing; sapi; fermentor; inokulum 


\section{PENDAHULUAN}

Desa Lelede merupakan salah satu desa yang terletak di Kecamatan Kediri, Kabupaten Lombok Barat, Provinsi Nusa Tenggara Barat. Pada tahun 2009, desa ini dimekarkan dari desa induk yaitu Desa Banyumulek. Lokasi Desa Lelede terletak pada jarak sekitar 14 kilometer dari Kota Mataram. Jarak tempuh dari Universitas Mataram ke Desa Lelede dapat dicapai dalam waktu 15 menit menggunaan kendaraan (Gambar 1). Karena desa ini dilalui oleh jalur langsung ke Bandara Internasional Lombok, maka desa ini sangat strategis.
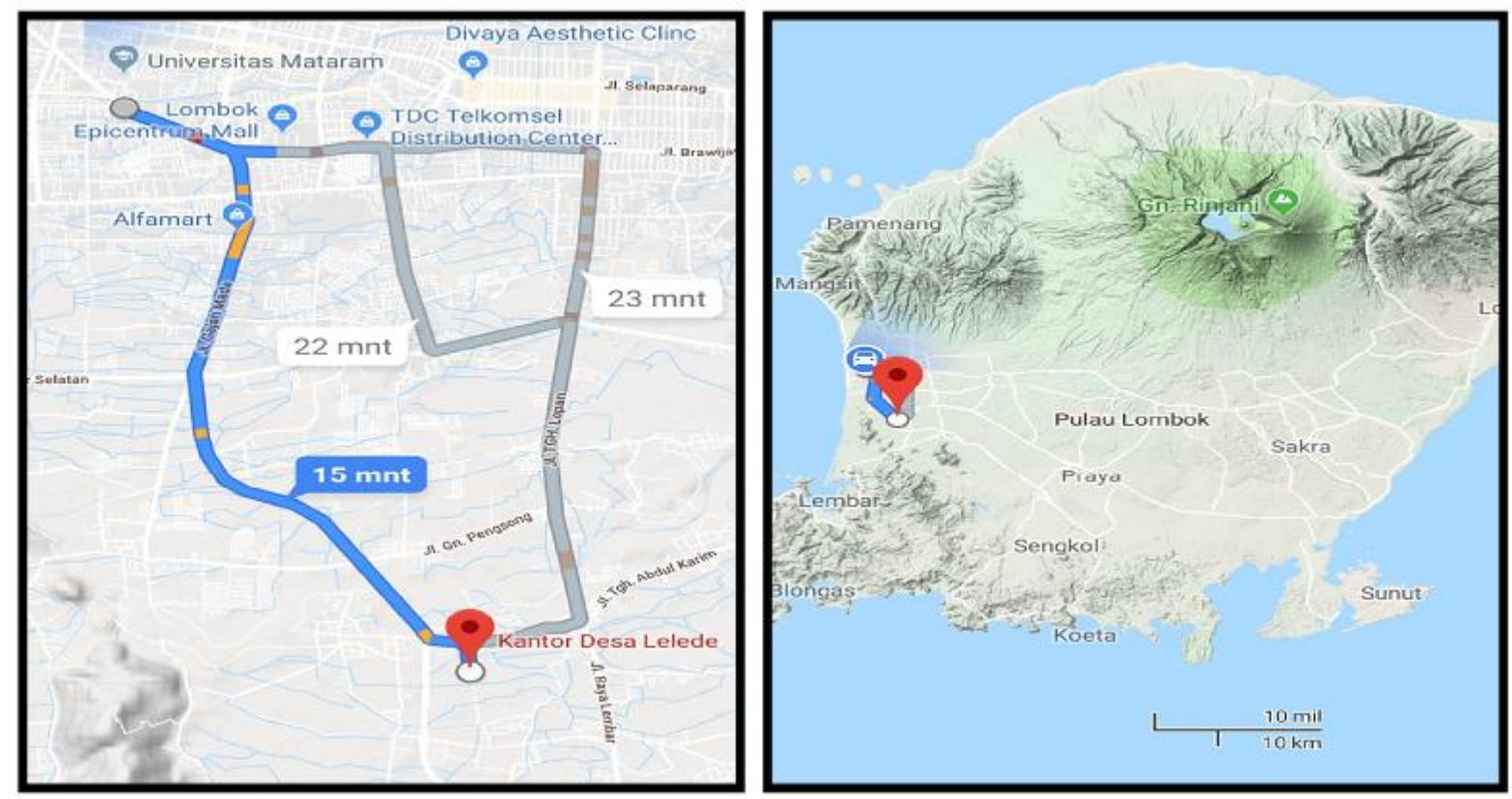

Gambar 1. Peta lokasi Desa Lelede dari Universitas Mataram

Sebagian besar penduduk Desa Lelede memiliki mata pencaharian sebagai petani, peternak, pedagang, dan buruh tani. Banyaknya masyarakat desa Lelede, terutama penduduk yang berada pada usia kerja, mengadukan nasibnya diperantauan sebagai TKI/TKW keluar negeri.Adapun beberapa negara yang menjadi tujuan masyarakat desa Lelede untuk bekerja antara lain Arab saudi, Korea, Hongkong, Taiwan dan sebagainya.

Berternak merupakan mata pencaharian utama bagi penduduk Desa Lelede, selain bekerja bertani maupun buruh tani. Jenis ternak yang dibudidayakan didominasi oleh ternak ruminansia seperti sapi dan kambing. Keberadaan rumput di areal persawahan maupun limbah pertanian, seperti jerami padi dan jagung serta limbah tanaman palawija lainnya merupakan sumber pakan yang murah bagi ternak yang dipelihara. Sumber pakan tersebut tersedia sepanjang tahun dan dapat diperoleh secara gratis di sekitar Desa Lelede dalam jumlah yang cukup memadai.

Budidaya ternak yang dilakukan masyarakat Desa Lelede masih bersifat tradisional. Pemberian pakan masih dilakukan secara sederhana tanpa memperhatikan unsur pemenuhan kebutuhan nutrisi ternak. Rumput maupun limbah pertanian yang dijadikan sebagai pakan, diberikan secara langsung tanpa proses pengolahan. Padahal, rumput maupun limbah tersebut mengandung serat kasar yang tinggi sehingga tingkat kecernaannya rendah (Ali, 2001). Untuk meningkatkan nilai nutrisi dan kecernaan 
rumput maupun limbah tersebut, diperlukan pengolahan maupun tambahan mikroorganisme yang berfungsi dalam membentuk pencernaan (Ashari et al., 2018).

Definisi probiotik berkembang setelah adanya data hasil penelitian ilmiah, seperti yang dikemukakan oleh Fuller (1992), bahan probiotik adalah makanan tambahan (feed supplement) berupa jasad hidup yang mempunyai pengaruh menguntungkan bagi ternak induk semangnya. Penggunaan probiotik untuk memperbaiki produktivitas ternak semakin banyak menarik perhatian para peneliti maupun praktisi peternakan. Probiotik didefinisikan sebagai mikroorganisme hidup tertentu yang diberikan kepada manusia atau ternak melalui pakan maupun air minum dan dapat memberikan efek positif karena dapat membantu pencernaan serat serta dapat memperbaiki keseimbangan mikroorganisme alami di dalam saluran pencernaan (Ali, 2016). Probiotik dapat memperbaiki saluran pencernaan dan meningkatkan kecernaan pakan, yaitu dengan cara menekan bakteri patogen dalam saluran pencernaan sehingga mendukung perkembangan bakteri yang menguntungkan yang membantu penyerapan zat-zat makanan (Kompiang, 2009).

Lebih lanjut dijelaskan bahwa probiotik juga bekerja dengan cara merubah metabolisme mikrobial dengan meningkatkan atau menurunkan aktivitas enzim, serta menstimulasi imunitas melalui peningkatan kadar antibodi atau aktifitas makrofag yang mampu mencerna mikroorganisme lainnya. Dengan meningkatnya jumlah mikroba akibatnya dapat meningkatkan penyerapan zat-zat organik. Hal ini sesuai dengan pendapat Harjanto (2005) bahwa semakin banyak mikroba maka jumlah pakan tercerna akan semakin tinggi pula. Mikroba dapat dikatakan mempunyai status probiotik bila memenuhi sejumlah kriteria seperti bisa diisolasi dari hewan inang dengan spesies yang sama, mampu menunjukkan pengaruh yang menguntungkan pada hewan inang, tidak bersifat patogen, bisa transit dan bertahan hidup dalam saluran pencernaan hewan inang (Maiti, 2007).

Adapun tujuan kegiatan ini adalah untuk melakukan difusi produk-produk bioteknologi seperti probiotik untuk meningkatkan kinerja produksi ternak ruminansia yang dipelihara oleh peternak. Selain itu, melalui kegiatan ini diharapkan produk-produk teknologi yang dihasilkan melalui penelitian di Universitas Mataram dapat dimanfaatlkan oleh masyarakat.

\section{METODE}

\section{Waktu dan Tempat}

Kegiatan pengabdian ini dilaksanakan mulai tanggal 6 sampai 8 Maret 2019 di Balai Pengembangan dan Pengolahan Pakan Ternak Ruminansia (BP3TR), Desa Lelede, Kecamatan Kediri, Kabupaten Lombok Barat. Sedangkan untuk uji coba penggunaan probiotik pada ternak dilakukan secara langsung oleh peternak di tempat/kandang masing-masing.

\section{Tahapan Kegiatan}

\section{Sosialisasi probiotik}

Untuk meningkatkan pengembangan ternak baik itu ternak sapi dan kambing, telah dilakukan sosialisasi penggunaan probiotik dan pembuatan pupuk kompos yang bertempat di Kelompok Ternak Mule Solah Dusun Kebun Daye Indah Desa Lelede, Kecamatan Kediri, Kabupaten, Lombok Barat yang melibatkan sekitar 20 orang anggota kelompok. Sebagai pemateri juga dilibatkan pihak STIP yaitu bapak Nasrudin yang merupakan ketua di bagian Laboratorium Pembuatan Probiotik, sebagai narasumber dalam sosialisasi tentang "Penggunaan Probiotik dan Pembuatan Pupuk Kompos di Desa Lelede". 


\section{Persiapan pembuatan probiotik}

Pembuatan probiotik dimulai dengan melakukan persiapan terhadap alat-alat yang akan digunakan serta bahan-bahan yang diperlukan, penimbangan bahan, pencampuran bahan, inkubasi, proses penampungan probiotik, pengemasan, sosialisasi, dan penggunaan probiotik. Secara rinci, proses pembuatan probiotik dapat dilihat pada Gambar 2.

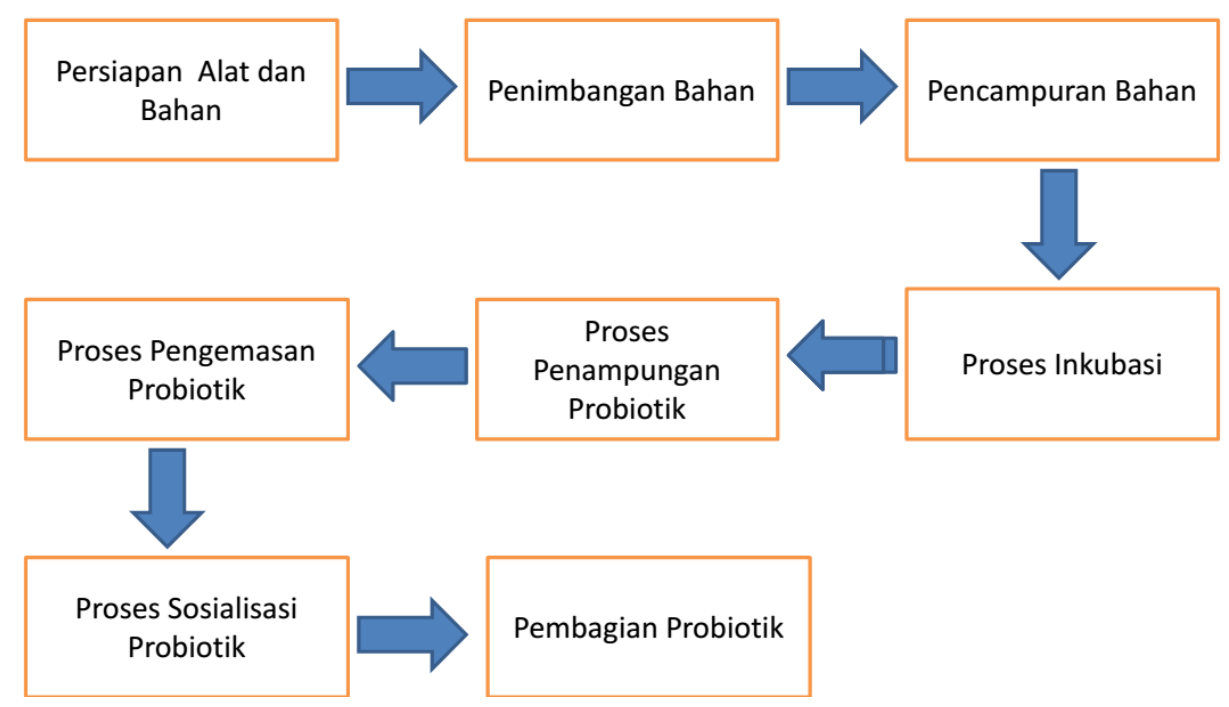

Gambar 2. Proses produksi probiotik

Untuk tumbuh, probiotik membutuhkan protein, sumber energi, dan mineral. Adapun bahanbahan yang diperlukan untuk pembuatan media probiotik dapat dilihat pada Tabel 1. Media tumbuh probiotik terdiri dari protein mix, glukosa, mineral mix, dan molases sebagai sumber energi. Jumlah penggunaan bahan-bahan tersebut tergantung dari volume probiotik yang akan dibuat yaitu sekitar 0,5 L sampai $100 \mathrm{~L}$.

Tabel 1. Komposisi Media Probiotik

\begin{tabular}{|c|c|c|c|c|c|c|c|}
\hline \multirow{2}{*}{ Bahan } & \multirow{2}{*}{ Jumlah (\%) } & \multicolumn{6}{|c|}{ Volume Pembuatan Probiotik (Liter) } \\
\hline & & 0.5 & 1 & 10 & 20 & 50 & 100 \\
\hline Protein Mix & 8 & 40 & 80 & 800 & 1600 & 4000 & 8000 \\
\hline Glukosa & 0.53 & 2.65 & 5.3 & 53 & 106 & 265 & 530 \\
\hline Mineral Mix & 0.4 & 2 & 4 & 40 & 80 & 200 & 400 \\
\hline Molases & 2.02 & 10.1 & 20.2 & 202 & 404 & 1010 & 2020 \\
\hline
\end{tabular}

Untuk pembuatan protein mix digunakan komposisi seperti tercantum pada Tabel 2, yaitu tersusun dari tepung kacang kedelai, tepung kacang hijau, tepung jagung, tepung ikan, dan ajiten. Seluruh bahan protein mix direbus 18 jam, ditunggu hingga mengental, kemudian ditambahkan air sebanyak jumlah air pada perebusan pertama. Setelah mendidih, hasil rebusan kemudian dapat disaring. 


\section{Tabel 2. Komposisi Protein Mix}

\begin{tabular}{lccccccc}
\hline Bahan & Jumlah & \multicolumn{6}{c}{ Volume Pembuatan Protein Mix (Liter) } \\
& $(\boldsymbol{\%})$ & $\mathbf{0 . 5}$ & $\mathbf{1}$ & $\mathbf{1 0}$ & $\mathbf{2 0}$ & $\mathbf{5 0}$ & $\mathbf{1 0 0}$ \\
\hline Tepung kacang kedelai & 5 & 25 & 50 & 500 & 1000 & 2500 & 5000 \\
Tepung kacang hijau & 0.5 & 2.5 & 5 & 50 & 100 & 250 & 500 \\
Tepung jagung & 2 & 10 & 20 & 200 & 400 & 1000 & 2000 \\
Tepung ikan & 3 & 15 & 30 & 300 & 600 & 1500 & 3000 \\
Ajiten & 1 & 5 & 10 & 100 & 200 & 500 & 1000 \\
\hline
\end{tabular}

\section{Pembuatan Probiotik}

a. Pembuatan inolukulum :

Inokulum adalah kultur mikrobia yang diinokulasikan ke dalam medium pada saat kultur mikriobia tersebut pada fase pertumbuhan (Anonim, 2012). Jumlah inolukulum yang digunakan $5 \%$ dari jumlah probiotik total yang akan dibuat. Misalkan kita akan membuat probiotik $20 \mathrm{~L}$, maka inokulum yang harus dibuat adalah $5 \%$ x $20 \mathrm{~L}=1 \mathrm{~L}$. Komposisi inokulum sama dengan komposisi pembuatan probiotik. Untuk itu, komposisi $1 \mathrm{~L}$ inokulum adalah $80 \mathrm{ml}$ protein mix, glukosa 5,3 g, mineral mix $4 \mathrm{~g}$, molases 20,1 ml. Seluruh bahan inokulum direbus dalam dandang sambil diaduk. Setelah rebusan mendidih tunggu hingga 20 menit (tidak perlu diaduk, dalam kondisi dandang tertutup), kemudian matikan kompor dan tunggu hingga dingin (dandang tetap tertutup untuk meminimalisir kontaminasi dengan lingkungan luar). Setelah dingin masukkan biakan bakteri $L$. Plantarum (5\% dari inokulum yang akan dibuat; misal untuk $1 \mathrm{~L}$ inokulum biakkan bakteri yang dibutuhkan sebanyak $50 \mathrm{ml}$ ), semprot ujung-ujung tutup dandang dengan alcohol $70 \%$ dan segera tutup rapat dandang dengan isolasi. Aduk dengan cara menggoncang dandang. Inkubasi pada suhu ruang selama 18 jam.

\section{b. Pembuatan probiotik}

Seluruh komposisi bahan probiotik direbus dalam fermentor. Setelah tanda penunjuk suhu di fermentor menunjukkan suhu $100^{\circ} \mathrm{C}$ dan penunjuk tekanan menunjukkan tanda $1.5 \mathrm{ATM}$ tunggu hingga 15 menit, kemudian matikan kompor kran pembuangan yang ada di tutup fermentor. Dinginkan fermentor. Setelah fermentor bersuhu normal kemudian masukkan inokulum dan seal tutup fermentor dengan isolasi. Inkubasi pada suhu ruang selama 18 jam dan probiotik siap di panen.

\section{HASIL DAN PEMBAHASAN}

Kesehatan hewan ternak sangat bergantung pada pakan yang dikonsumsi karena dengan menggunakan pakan yang sehat (mempunyai kandungan energi yang berasal dari karbohidrat dan lemak, protein, vitamin dan mineral), hewan ternak pun dapat tumbuh dan berkembang dengan baik. Pemberian probiotik dimaksudkan untuk meningkatkan kecernaan pakan karena probiotik memiliki kemampuan mencerna karbohidrat, protein maupun lemak (Ali, 2016). Probiotik juga diyakini dapat menjamin pembentukan secara efektif organisme yang bermanfaat dalam tubuh inang (hewan) terutama mikroorganisme yang berada dalam sistem pencernaan karena mampu memperbaiki keseimbangan mikroflora usus. Sehingga pemberian probiotik bertujuan untuk memperbaiki kondisi saluran pencernaan dengan menekan reaksi pembentukan racun dan metabolit yang dapat mendorong atau menyebabkan kanker (karsinogenik), merangsang reaksi enzim yang dapat menetralisir senyawa beracun yang tertelan atau dihasilkan oleh saluran pencernaan, merangsang produksi enzim yang 
diperlukan untuk mencerna pakan danmemproduksi vitamin serta zat-zat yang tidak terpenuhi dalam pakan.

Disamping itu penggunaan probiotik memberikan beberapa keuntungan lain diantaranya: memperbaiki laju pertumbuhan ternak, memperbaiki penggunaan makanan melalui peningkatan efisiensi dari proses pencernaan, meningkatkan produksi telur, dan memperbaiki kesehatan dengan ketahanan terhadap infeksi penyakit lain oleh antagonisme langsung atau dengan stimulasi kekebalan. Beberapa penelitian menunjukkan penggunakan probiotik pada ransum dapat meningkatkan produktivitas ayam ras pedaging dan petelur serta ayam kampung. Disamping itu, penambahan probiotik dalam ransum ternak sapi Bali telah memberikan pengaruh yang positif terhadap kinerja mikroba rumen (Hau, 2005).

Probiotik dapat diklasifikasikan ke dalam dua tipe, yaitu kultur mikrobial hidup, sebagai contoh adalah probiotik starbio dan produk mikrobial fermentasi, contohnya adalah kultur yeast (Saccharomyces cerevisiae), Aspergilllus niger, A. oryzae dan Lactobacillus acidophilus (Chen et al, 2004). Probiotik dapat diberikan secara langsung melalui mulut atau dicampur dengan pakan maupun air minum. Probiotik yang baik harus efektif, dengan memenuhi beberapa kriteria: memberi efek yang menguntungkan pada induk semang, tidak menyebabkan penyakit dan tidak beracun, mengandung sejumlah besar sel hidup, mampu bertahan hidup di dalam kegiatan metabolisme dalam usus, tetap hidup dalam kurun waktu penyimpanan yang lama dan kondisi lapangan, mempunyai sifat sensor yang baik, dan yang pasti harus menguntungkan bagi peternak.

Probiotik merupakan produk teknologi yang belum dikenal oleh masyarakat maupun peternak secara luas. Untuk itu, sosialisasi dilakukan kepada masyarakat guna memberikan pemahaman tentang probiotik, manfaat penggunaannya pada ternak, maupun cara pembuatannya dengan menggunakan bahan-bahan yang mudah diperoleh di sekitar pemukiman peternak. Gambar 3 menampilkan proses sosialisasi probiotik kepada masyarakat terutama peternak.

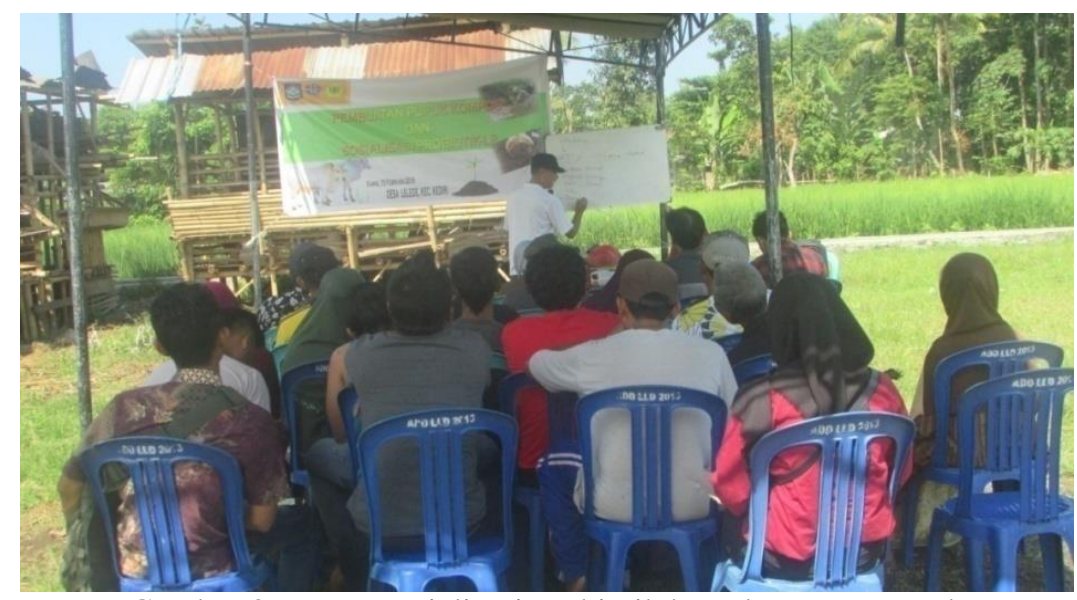

Gambar 3. Proses sosialisasi probiotik kepada para peternak

Setelah peternak selaku pengguna probiotik memahami pengertian probiotik serta manfaat maupun teknik pembuatannya, maka dilakukan langkah selanjutnya untuk menghasilkan probiotik. Untuk pembuatan probiotik telah digunakan beberapa bahan sebagai media yaitu tepung kacang hijau, tepung jagung, tepung kedelai, tepung ikan, glukosa, dan mineral mix. Gambar 4 menunjukkan bahanbahan yang diperlukan untuk pembuatan media probiotik serta proses pencampuran bahan-bahan. 

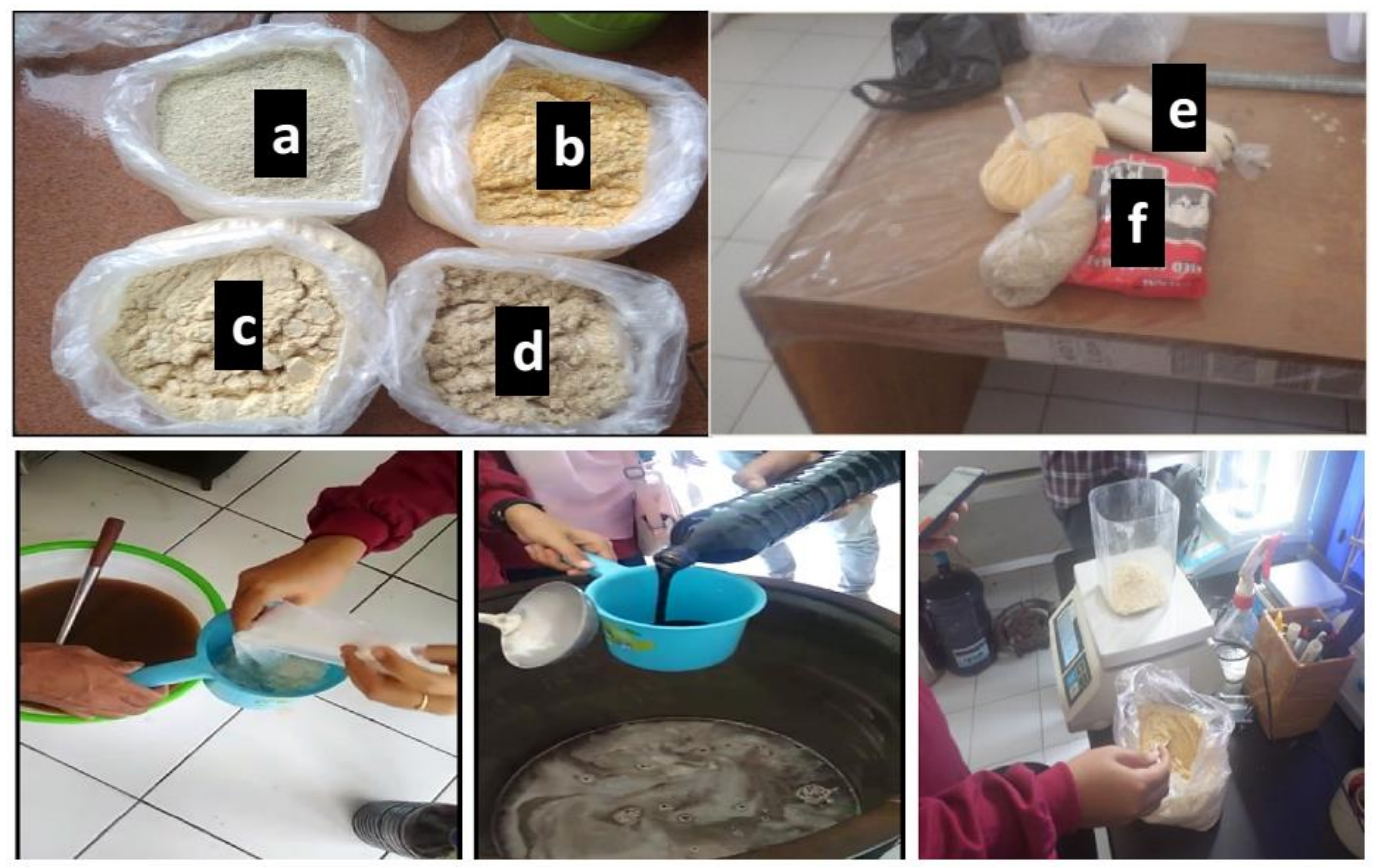

Gambar 4. Bahan pembuatan media probiotik yang terdiri dari a) tepung kacang hijau, b) tepung jagung, c) tepung kedelai, d) tepung ikan, e) glukosa, f) mineral mix, dan proses pencampuran.

Bahan-bahan tersebut kemudian ditimbang dan dicampur sesuai dengan komposisi yang telah ditentukan sebelumnya. Gambar 5 menunjukkan proses pencampuran bahan-bahan yang diperlukan sebagai media tumbuh probiotik. Bahan-bahan yang digunakan di atas mengandung energi dan sumber protein yang diperlukan oleh probiotik untuk tumbuh dan berkembang (Ali et al., 2018). Untuk menghasilkan media tumbuh yang baik, maka ketepatan jumlah timbangan sangat diperlukan.

Setelah bahan-bahan tersebut dilarutkan, kemudian dimasukkan ke dalam wadah yang dilanjutkan dengan inkubasi selama 18 jam guna memungkinkan larutnya nutrisi-nutrisi pada bahan ke dalam air media. Waktu inkubasi selama 18 jam tersebut dapat memungkinkan sebagian besar nutrisi bahan-bahan media akan terlarut ke dalam air. Proses inkubasi media dapat dilihat pada Gambar 5.

Pada waktu yang bersamaan, inokulum probiotik diinokulasikan ke dalam media untuk pembuatan inokulum yang dilanjutkan dengan proses pencampuran dengan cara diguncang. Inkubasi dilakukan selama 18 jam pada suhu ruang. Setelah proses inkubasi, media kemudian disaring untuk memisahkan bagian padat yang merupakan ampas dengan cairan yang merupakan media yang siap digunakan untuk menumbuhkan probiotik.

Untuk menumbuhkan probiotik, inkubasi dilakukan pada suhu ruang selama 18 jam. Pada masa inkubasi ini, probiotik akan berkembang biak dengan cepat. Adanya shaker sangat bermanfaat untuk menyediakan oksigen terlarut bagi probiotik. Hal ini disebabkan karena, kelarutan oksigen di dalam air 1000x lebih sulit dibandingkan dengan kelarutan gula (Ali et al., 2015). 

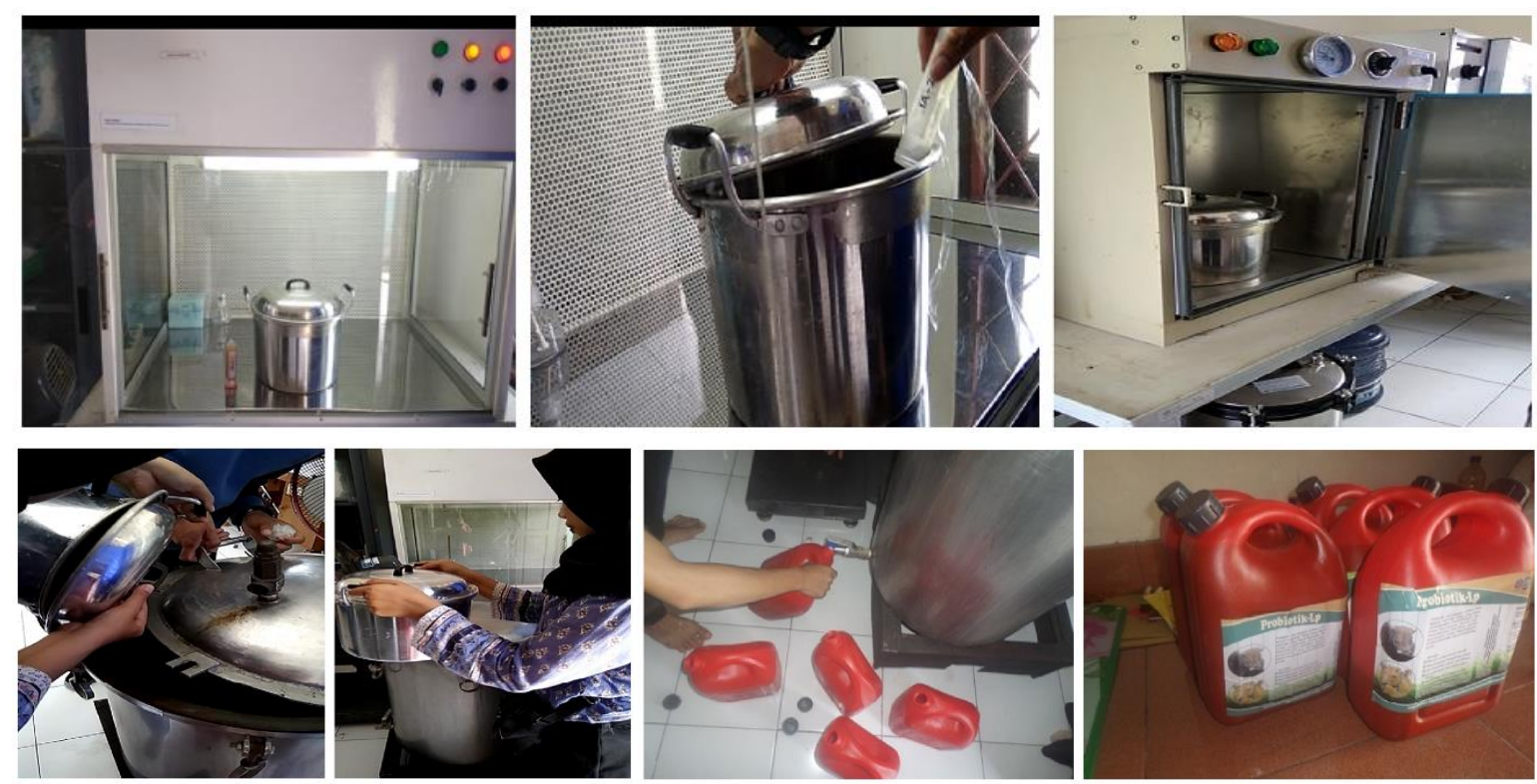

Gambar 5. Proses inkubasi media, pembuatan inokulum probiotik selama 18 jam, dan produksi probiotik

Dihasilkannya probiotik yang berkualitas ditandai diantaranya oleh adanya perubahan bau media yang disebabkan oleh proses fermentasi. Tahap akhir yang dilakukan adalah pengemasan probiotik menggunakan kemasan cerigen plastik volume $5 \mathrm{~L}$. Setelah dilakukan pelabelan dengan label cara penggunaan probiotik, maka probiotik yang telah dihasilkan itu siap diberikan kepada peternak untuk digunakan pada ternaknya.

\section{KESIMPULAN DAN SARAN}

Pembuatan Probiotik memerlukan beberapa alat dan bahan seperti kompor gas, tabung inkubasi, gayung, panci, alat pengaduk, tepung kedelai, tepung jagung, tepung ikan, tepung kacang hijau, glukosa, molasses, mineral mix, dan ajiten. Bahan ditakar terlebih dahulu kemudian dicampur merata, selanjutnya dimasukkan ke dalam tabung inkubasi untuk dimasak selama kurang lebih 18 jam. Setelah proses tersebut selesai, selanjutnya probiotik tersebut ditampung untuk kemudian dikemas. Jika semua proses tersebut selesai dilakukan, maka probiotik tersebut dapat diaplikasikan kepada hewan ternak. Untuk menghasilkan probiotik yang berkualitas, disarankan agar setiap isolat probiotik harus menggunakan isolat asli yang tersimpan dalam bentuk stok gliserol. Sehingga kontaminan yang dapat mendatangkan efek negatif bagi probiotik dapat dihindari. Selain itu, penggunaan beberapa media alternatif yang murah, mudah diperoleh, dan tersedia secara lokal sangat diperlukan.

\section{Ucapan Terima Kasih}

Ucapan terima kasih disampaikan kepada Balai Pengembangan dan Pengolahan Pakan Ternak Ruminansia (BP3TR) di STIP Lelede yang memberikan fasilitas dalam pembuatan probiotik. Demikian pula kepada para peternak di Desa Lelede Kecamatan Kediri Kabupaten Lombok Barat. 


\section{DAFTAR PUSTAKA}

Ali, M. 2001. Kinetika Fermentasi Rumen dan Degradasi Sekam Padi yang Dihidrolisis Menggunakan Kapur Tohor $(\mathrm{Ca}(\mathrm{OH}) 2)$ dan Asam Cuka (CH3COOH). Buletin Peternakan, 25, 181-189.

Ali, M. 2016. Pengantar Bioteknologi. Mataram University Press, Mataram.

Ali, M., Ismaini, Depamede SN., Setyono BH., Mukhlis A., Amin M., Ashari M. 2015. Stirred Bioreactor for The Robustness Production of Recombinant GST.VP28 in Fed-batch Cultivation of Escherichia coli. Scientific Study \& Research, 16, 245 - 252.

Ali, M., Karni I., Amin M., and Ichsan M. 2018. Development of Growth/ Media for Bacillus amyloliquefaciens subsp. plantarum, A Poultry Probiotic Candidate. J. Applied Bio. Sci. 12 (1): 46-50.

Anonim. 2012. Buku Petunjuk Praktikum Teknologi Fermentasi, Institut Pertanian STIPER. Yogyakarta.

Ashari, M., Wariata IW., Ali M., dan Amin M. 2018. Pemanfaatan Ampas Tahu Sebagai Bahan Pengikat Silapro (Silase Probiotik) untuk Penggemukan Kambing Peranakan Ettawa. Abdi Insani, 5, 69-77.

Chen, C .R., B . Yu and P.W .S: CHlou. 2004. Roughage energy and degradability estimation with Aspergillus oryzae inclusion using dairy in vitro fermentation. Asian-Aust. J. Anim. Sci. 17: 53 - 62

Fuller, R.1992. Probiotics the Scientific Basis. Chapman and Hall, London.

Harjanto, K. 2005. Pengaruh Penambahan Probiotik Bio H+ Terhadap Kecernaan Bahan Kering dan Bahan Organik Pakan Sapi PFH Jantan. Skripsi Fakultas Pertanian UNS. Surakarta.

Hau, D. K., M. Nenobais, J. Nulik \& N. G. F. Katipana. 2005. Pengaruh Probiotik Terhadap Kemampuan Cerna Mikroba Rumen Sapi Bali. Seminar Nasional Teknologi Peternakan dan Veteriner: $171-180$.

Kompiang, I Putu. 2009. Pemanfaatan Mikroorganisme Sebagai Probiotik Untuk Meningkatkan Ternak Unggas di Indonesia. Pusat Penelitian dan Pengembangan Peternakan: Bogor.

Maiti, K. 2007. Kurkumin Phospholipid Complex.Preparation, Evaluation and PharmacokineticStudi in Rats.Int. J. Pharm. 330(1-2), 155-63. 